\title{
STUDY OF PARAMETERS REQUIRIED FOR QUANITIFICATION OF SURFACE DRAINAGE IN COMMAND AREA: A CASE STUDY OF BLOCK 9B2 IN PHASE-1 OF SARDAR SAROVAR PROJECT
}

\author{
Saeed Ahmed G.Khokhar', Siddharth N. Gupte' ${ }^{2}$, Vikram J.Patel ${ }^{3}$ \\ ${ }^{l}$ Asst.Professor\&Head, Civil Engineering Department, Parul Institute of Engineering \& Technology, Vadodara, \\ Gujarat, India \\ ${ }^{2} P G$ Student, Civil Engineering Department, Parul Institute of Engineering \& Technology, Vadodara, Gujarat, India \\ ${ }^{3}$ Asst.professor, Civil Engineering Department, R.C. Patel Institute of Technology, Shirpur, Maharashtra, India
}

\begin{abstract}
Agriculture and, consequently, food production depend, among other factors, on the proper management of water. Land drainage, an integral component of water management, is well known to have ameliorated salinity and waterlogging problems in rain fed and irrigated agriculture. In so doing, it has contributed substantially to sustainable agricultural development through enabling increased crop production, decreased farming costs, and the maintaining of soil quality. In areas where rainfall is excessive, it is necessary to manage land drainage, both surface and subsurface, in order to prevent waterlogging. In areas where rainfall is deficient, drainage management is still important in order to minimize soil salinization.

In the arid and semi-arid regions, soil salinity still limits crop production significantly. Hence, it has a negative effect on food security. In the wetter regions, flooding and waterlogging still limit crop production in many parts of the world. As the global population and the demand for food increase, additional new drainage systems will be installed in a broader range of climate, soil and hydrological conditions, and existing systems will be renovated. This study on surface drainage is intended to serve as a reference for an integrated drainage system. The main text of this study provides critical general information about the agricultural surface drainage.
\end{abstract}

Keywords: Surface Drainage, Rainfall, Runoff, Minors, Irrigation, Crops.

\section{INTRODUCTION}

Hydrology is the science that treats of the waters of the earth, their occurrence, circulation and distribution, the chemical and physical properties, and their reaction with their environment, including their relation to living things. The rainfall runoff process is a complicated process which is governed by and involves many complex processes such as infiltration, seepage, percolation, overland, channel and groundwater flows, evaporation, transpiration etc. however, basically two stages are involved in rainfall runoff process :

1. The process by which the rainfall on the land surface becomes effective or excess rainfall

2. The process by which the excess or effective rainfall becomes runoff at the outlet of the catchment or drainage basin.

The drainage and flood control form an integral part of the comprehensive planning process of water management. In order to plan and implement appropriate drainage measures in different types of areas such as agricultural area, forest areas, urban areas, etc. one has to study and understand the rainfall runoff process of such areas, so that runoff which is an essential parameter for planning of drainage measures, could be properly estimated. The drainage basin or catchment forms part of a larger environmental system.
With the increasing interference of man in the hydrological cycle, the rainfall runoff process is considerably influenced.

The problem of waterlogging is becoming a matter of deep concern in many parts of the country and with more and more areas coming under irrigation; it may become very serious unless proper protective drainage measures are planned. Planning of surface drainage systems, the following aspects have to be studied:

1. Rainfall patterns and frequencies

2. Land use and land cover characteristics

3. Human interference in the drainage basin

4. The purpose of the drainage system, whether for agricultural area or urban area and whether as a remedial measure or as a preventive measure.

5. Operational aspects such as gravity drainage versus pump drainage

6. Hydrological effects of drainage measures e.g. effect on peak floods.

Agricultural drainage may be defined as the removal and disposal of excess water, salt from Agricultural land at a rate which will permit normal plant gro water logging as (National commission on Agriculture, 1976); “An area is said to be water logged when the water table rises to an extent that the soil pores in the root zone of a crop becomes 
saturated resulting in restriction of the normal circulation of air, decline in the level of the oxygen and increase in the level of carbon-dioxide"

The problem of water logging is becoming more \& more serious with the development of new irrigation projects \& other Construction which obstruct the natural drainage courses. Along with this very little attention has been given in cleaning \& maintaining the existing drainage channels thus adding more seriousness to the problem of water logging.

The aspect of economic justification must be reconciled the prime objective should be to design and construct a drainage system which has optimum integration of soils, crops, irrigation and drainage.

\subsection{Surface Drainage Principles}

Surface drainage is accomplished in two general ways: (a) excess water is collected and removed from the ground surface within the area affected; or, (b) by means of construction outside the area, water is diverted away from the area to be protected. In either case, the system is conveniently divided into three functional parts:

1. Collection system. Bedding, field ditches, row ditches, or diversion ditches are part of the system that first picks up water from the land.

2. Disposal system. This is the part of the system that receives water from the collection system and conveys it, usually in an open ditch, to the outlet.

3. Outlet. This is the end point of the drainage system under consideration.

\subsection{Classification of Drains}

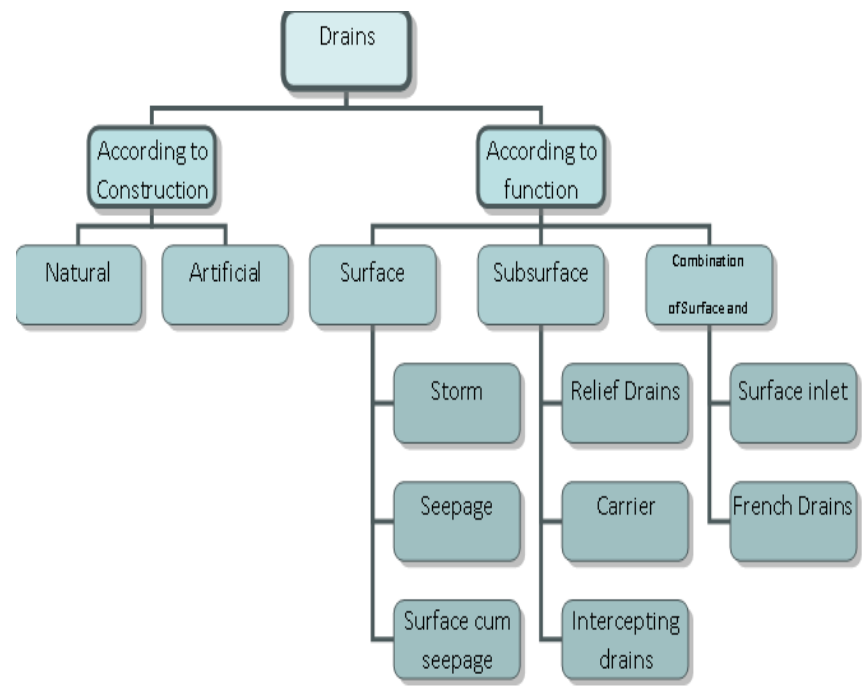

\section{Surface-Drainage Systems}

The basic surface-drainage systems are the parallel, the random, and the cross-slope or diversion system. The system to be used will depend upon the requirements of the site. The system used should -

1. Fit the farming system.
2. Cause water to flow readily from land to ditch without harmful erosion or deposition of silt.

3. Have adequate capacity to carry the flow.

4. Be designed for construction and maintenance with appropriate equipment locally available.

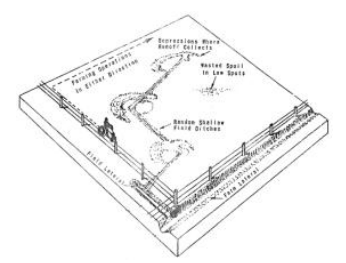

Fig -1: The random system

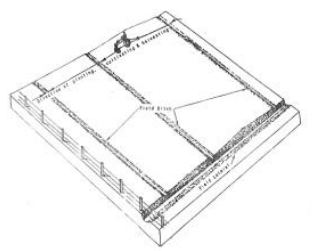

Fig -2: The parallel system

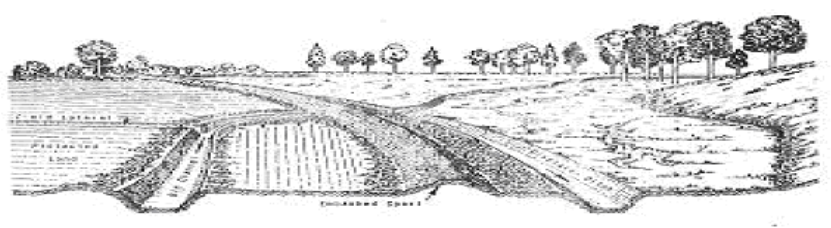

Fig -3: The cross-slope system (diversion system)

\section{LITERATURE REVIEW}

M.M. Pandey (2009) presented Drainage has become the part of integrated water management, removing or conserving water as required and also being much concerned about water quality and environmental values. The Food and Agriculture Organization of the United Nations (FAO) assessment (FAO 1996) puts the developed world cropland as 1500 million ha (Mha) of which about 1200-1250 Mha are used for rain fed cropping while about 270 Mha (about 18 per cent of the total cropland) have irrigation facilities. The area provided with improved drainage is estimated to be of the order of 150-200 Mha (1014 percent of the total crop land). Land drainage and irrigation are complementary to each other for maintaining sustainable agriculturalproductivity. Large areas have been degraded in the country due to the problem of water-logging and salinity, especially in the irrigated alluvial tracts in north-west India (Hariyana, Punjab, Gujarat etc.) In India about .528 Mha and 7.006 Mha land is having water-logging and salinity problems respectively. A survey conducted for assessing drainage problems in Madhya Pradesh, revealed that at present, 1.06 per cent, 1.20 per cent and 0.90 percent of command areas are affected due to water-logging in Chambal, Tava and Barna respectively. Farmers of temporary water-logged lands and low lying areas are not able to remove excess water from their fields due to lack of natural or manmade drainage network /grid. Farmers $n$ adjoining areas of natural drains are often using open ditches for excess water removal from their fields. Therefore, 
farmers either leave the fields fallow during monsoon season or they get very low yield from their crops. In order to restore these degraded lands drainage becomes an essential measure. Drainage measures consist of mainly to evacuate salts and water from the crop root zone.

The National Water Policy (2002) emphasized adopt on of drainage systems and reclamation measures for waterlogged areas for sustainable development. Good drainage absorbs and stores more rainfall reducing runoff from the soil surface that causes soil erosion, reduces the chances of water borne diseases, allows plant roots to receive enough oxygen to mature properly, improves seeds germination due to increased soil surface temperature and increases the number of days available for planting and harvesting crops. Land drainage thus increases crop yields and land value.

Fausey (2008) suggested that, Drainage is an agricultural water management practice that has been used for many centuries. 1 In early times, development of cities and commerce was dependent upon stable and bountiful agriculture requiring fertile soils and adequate rainfall or irrigation water. There is evidence of failure of early irrigation-based agriculture due to salt accumulation in the soils because of not understanding how to use drainage to leach the salt from the soil.2 Areas with adequate rainfall to support permanent agriculture frequently also need drainage to manage excess water in the soil. Soils in low-lying areas were recognized by early farmers as the more fertile and productive soils, but these soils were also subject to periodic flooding and crop loss or damage. The goals for early drainage works seem to be centered on removing standing water from crops. Archeological evidence from the Mayan culture in Central America indicates that ridges or raised beds were constructed and used as planting zones to avoid inundation of crops, a very early form of surface drainage. Ancient Greek and Roman writings included instructions for construction of both surface and subsurface drains.1 Agriculture has evolved to a highly mechanized industry, and this has intensified the demands on drainage. Modern goals for drainage include a trafficable soil surface for timely planting and harvesting of crops using large machines; an aerated root zone that promotes good crop nutrition and minimizes disease organisms; sustained high crop yields; and an ability to maintain the salt balance within the soil profile.

Muhammad Saeed, et al. (2007)presented Different drainage measures like surface drainage, tubewells and subsurface pipe drains were practiced for removing the excess or unwanted water from agricultural lands. The maintenance of drains is very essential as properly maintained surface drains can reduce the need of costly subsurface drainage systems. The results of the work carried out concluded that a well-maintained service road could provide access to the entire drainage system. The service roads can be maintained by tractor front blade. The mechanical method for cutting of weeds is expensive as compared to manual method. The biological approach with farmers' participation can help to curtail the $30 \%$ O\&M expenditures. The fully grownup eucalyptus trees not only can help to lower the water table but also reduce side sloughing and growth of vegetation in bed under shadows. The medium size drain should be maintained by tractor-operated equipment like flail mowers and front blade etc. The small drains should be maintained by manual method by department, whereas the farm drains of bed width less than 10 feet may be maintained by farmers.

Frank van Steenbergen et-al (2006) presented, In most irrigation and drainage management systems, a financial balance is hardly ever reached. This is mainly because only farmers are charged for irrigation and drainage services. This paper describes a new approach to water management and shows how it would permit reaching better financial results in water management projects. This so-called "WaterFrame" approach is an integrated perspective where water is seen as an important ingredient in a local development area. According to this approach, good water management could create new values in the area, which benefit not only farmers but also other individuals. Charges could then be put to those new stakeholders. The paper asserts the importance of creating values through business opportunities (commercial use of vegetation in waterways, development of waterfront property, etc.) using the income from this to support water management projects. Operational performance is thus improved and enhanced greatly through public private partnerships.

Abdel-Dayem (2001) presented, the state of development of drainage in arid and semi-arid countries is lagging far behind the development of irrigation. This leaves the worlds' irrigated agriculture at high risk of losing productive lands to waterlogging and salinization. As development of new irrigation projects will not likely happen anymore as in the sixties and seventies, drainage of existing irrigated lands can contribute to food security both by increasing the productivity and avoiding any further decline in the yield due rising water tables and/or salinity. Serious development of irrigated agriculture on a sustainable basis needs to address the drainage needs within a sound policy, institutional, technical, economic and social framework.

\section{OBJECTIVES OF PRESENT STUDY}

The objectives of the present study are

1. To determine the runoff in all 13 minors i.e. Hetampura , Kundhela ( R), Kundhela (L) , Alhadpura, Dhaniyavi, Shahpura, Voragamdi, Unitya, Varnama, Vadsala, Karali, Itola, Pingalwada in Block $9 \mathrm{~B}_{2}$ in phase $-\mathrm{I}$ of Sardar Sarovar Project,

2. To study canal water releases.

3. To determine crop water requirement in the study area for year 1991-92 to year 2009-10.

4. To assess the accumulated water in the study area under each minor for three different scenerios.

A. For preimplemention of the Sardar Sarovar Project without considering crop water requirement. 
B. For Post implementation of Sardar Sarovar Project considering crop water requirement for the present situation

5. To evaluate the capacity of all three drains in Hetampura minor of Block $9 \mathrm{~B}_{2}$

\section{DATACOLLECTION AND ANALYSIS:}

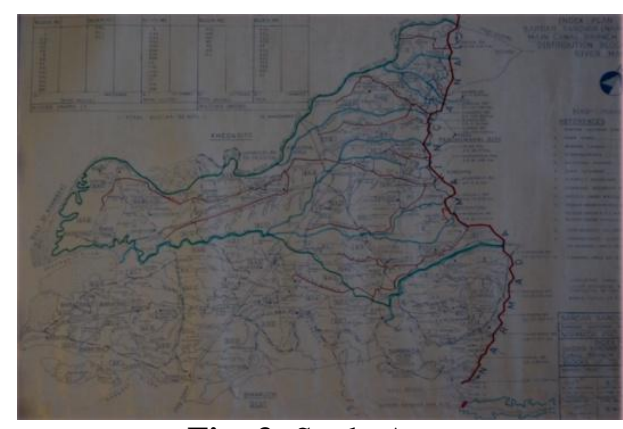

Fig -3: Study Area

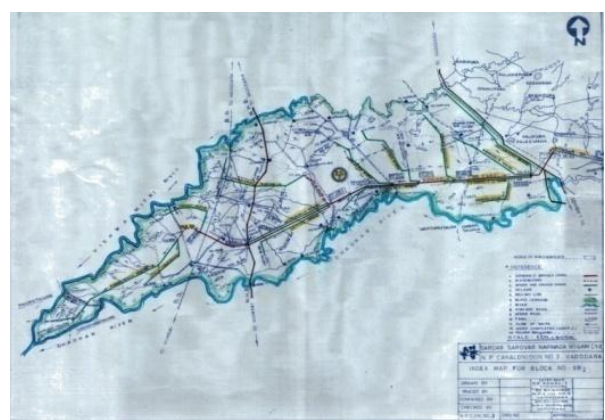

Fig -4: Index Map for Block No. 9B ${ }_{2}$

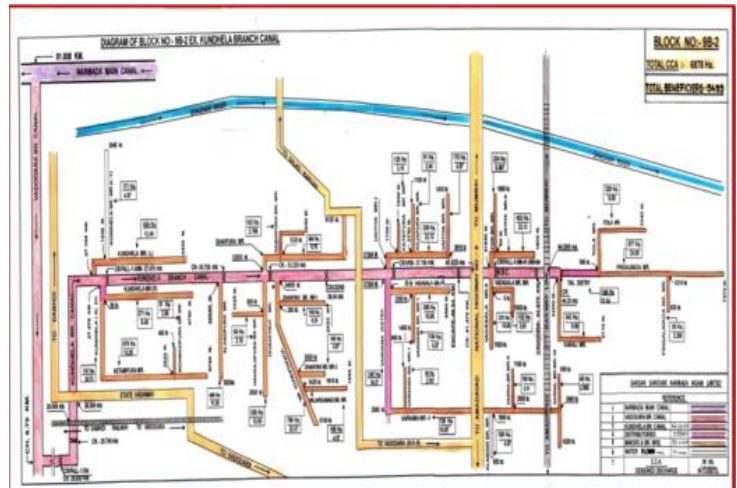

Fig -5: Diagram of Block No. 9B2 Ex. Kundhela Branch Canal

For the present study area i.e. block no. $9 \mathrm{~B}_{2}$ in phase- 1 of the Sardar Sarovar project. It is the proposed to be brought under irrigation, geographically lies between the $22^{\circ} 14^{\prime}$ to $22^{\circ} 07^{\prime}$ north latitudes and $73^{\circ} 05^{\prime}$ to $73^{\circ} 20^{\prime}$ east longitudes. The command area of block $9 \mathrm{~B}_{2}$ is bounded by Dhadhar river on south-east side and Vishawamitri river on Northwest side.

The Kundhela Branch canal flows in the east west direction in the lower middle portion of the command area and tails after crossing the Vadodara-Mumbai railway line.It is proposed to scatter $34 \mathrm{~cm}$ irrigation water through Kundhela branch canal with a water input of 4.67 cumecs/ha. Main crops grown in command area are Cotton, Tur, Deevela, Maize, Wheat, Juwar and other Crops, Vegetables.

Various data are collected to meet the requirements of objectives of this study which are as under.

* Topographical maps. Combined Index map, key map, village service area maps showing minors, survey of India map showing Drainage network of command area block no. 9B 2 ex-Kundhela Branch.

* Geohydrological data.

* Water table data

* Soil characteristics data

* Irrigation data: moisture holding capacity of soil, land use cropping pattern, types of crops, metrological data

* Existing Drainage data

* Meteorological Data:

$>$ Daily Rainfall

$>$ Evaporation

$>$ Temperature wind velocity Relative humidity etc

\begin{tabular}{|l|l|l|}
\hline SR.NO & NAME OF MINOR & AREA(IN HA.) \\
\hline 1 & Hetampura minor & 176 \\
\hline 2 & Kundhela(R)minor & 126 \\
\hline 3 & Kundhela(L)minor & 222 \\
\hline 4 & Alhadpura & 182 \\
\hline 5 & Dhaniyavi minor & 168 \\
\hline 6 & Shahpura Minor & 206 \\
\hline 7 & Voragamdi Minor & 244 \\
\hline 8 & Unitiya Minor & 460 \\
\hline 9 & Varnama Minor & 359 \\
\hline 10 & Vadsala Minor & 382 \\
\hline 11 & Karali minor & 172 \\
\hline 12 & Itola minor & 160 \\
\hline 12 & Pingalwada minor & 183 \\
\hline TOTAL & $\mathbf{6 8 7 8}$ & $\mathbf{3 0 4 0}$ \\
\hline
\end{tabular}

\subsection{Methodology for Computing Runoff using SCS - CN Method}

Sample calculation for Hetampura Minor

Step - 1: Determine the size of the drainage watershed and the extent of different types of soils and land use. Evaluate the area as percent of the total area under various hydrologic soil groups. The AMC is estimated from the 5 - day antecedent rainfall. The rainfall limits are plotted as boundary points for the AMC groups. No upper limit is intended for AMC - III.

Step -2: Collected empirical data of Block $9 \mathrm{~B}_{2}$, study area and design Tables/Charts for agricultural drainage.Find out Correction Factor From Table 3 for all minors of Kundhela Branch Canal of Phase-1

\section{Referring Existing Data of Study Area}

Geology : alluvial soils (Mixed type deep)

Soil texture: Fine to medium textural groups having sandy clay to clay texture. 
Topography: slope gradient range $-0 \%$ to $1 \%$

Meteorological Data: climate of Area - Sub Humid, Rainy days $-15^{\text {th }}$ June to $15^{\text {th }}$ Sept.

Drainage $\boldsymbol{\&}$ Permeability: very slow to moderate

Land use \& vegetation: Kharif \& Rabi seasons. Crops Tuver, cotton \& sugar cane

Step - 3 (From Table 1): Selection of Antecedent moisture condition \& initial abstractions

Select AMC - I for Lowest runoff potential

Initial abstraction Ia $=0.3$ SFrom (Table 5.4)

Hydrologic soil groups for determining runoff potential:

Select Group - B, Runoff potential - Moderately Low

From (Table 5.5), Runoff curve numbers for hydrologic soil cover complexes

Select: Land use -

Cover treatment or practice -

cultivated

Hydrologic condition -

straight row

for Group - B

Good

$\mathrm{CN}=75$

\section{Step - 4 (From Table 7):}

Hydrologic conditions -

Good

Vegetation condition -

Protected from grazing,

litter and shrub cover the soil(Forest \& Tree crops)

From Table 5.8 corrected to curve numbers for antecedent moisture conditions of the watershed.

Precipitation, $\mathrm{P}=$ Rainfall $\mathrm{x}$ Correction factor

From Table 3 select area wise correction factor for rain fall.Potential maximum retension, $S=\frac{25400}{C N}-254$

Selected, Ia $=0.3 \mathrm{~S}$

Runoff, $Q=\frac{(P-I a)^{2}}{P-I a+S}$ in $\mathrm{mm}$

Volume of $\operatorname{runoff}(\mathrm{Q})=10 \times$ Runoff (in $\mathrm{mm})$

x Area in $\mathrm{Ha}$

Volume of runoff (Q) Calculated in Ha.m or $\mathrm{m}^{3}$

\section{SUMMARY OF METHODOLOGY}

- Analyze the rainfall data and determined the runoff for all 13 minors.

- Determined date of maximum runoff and considered it as base day.

- $\quad$ As per base day, crop water requirement (Cu.m. per day) is found out.

- From canal water released data, water releases on base day is observed.

- Considering from year 1991-92 to 2005-06, as preimplementation of Sardar Sarovar Project, and from year 2006-07 to year 2009-10 as postimplementation of sardar sarovar project, for the area under study, the value of accumulation of water is calculated.

Accumulation of water (Cu.m./day) $==$

$\{$ Maximum runoff volume (Cu.m./day) $\}+$

\{Canal water releases (Cu.m./day)on base day $\}-$

\{Crop water requirement (Cu.m./day) on base day\}

- $\quad$ The water accumulated and the discharge carrying capacity of the three drains under Hetampura minor are compared and analyzed.

Table-1: Maximum runoff, mm from year 1991-92 to 200910 (in $\mathrm{mm}$ )

\begin{tabular}{|l|l|l|l|}
\hline $\begin{array}{l}\text { SR. } \\
\text { NO }\end{array}$ & YEAR & BASE DAY & TOTAL \\
\hline \multicolumn{3}{|l|}{ Pre implementation of Sardar Sarovar Project } \\
\hline 1 & $1991-92$ & $24 / 7 / 1991$ & 496.14 \\
\hline 2 & $1992-93$ & $13 / 8 / 1992$ & 388.73 \\
\hline 3 & $1993-94$ & $12 / 7 / 1993$ & 1245.89 \\
\hline 4 & $1994-95$ & $7 / 9 / 1994$ & 3034.48 \\
\hline 5 & $1995-96$ & $20 / 7 / 1995$ & 538.8 \\
\hline 6 & $1996-97$ & $28 / 7 / 1996$ & 1008.57 \\
\hline 7 & $1997-98$ & $25 / 6 / 1997$ & 1020.66 \\
\hline 8 & $1998-99$ & $15 / 9 / 1998$ & 1451.61 \\
\hline 9 & $1999-2000$ & $18 / 6 / 1999$ & 312.26 \\
\hline 10 & $2000-01$ & $14 / 7 / 2000$ & 653.17 \\
\hline 11 & $2001-02$ & $16 / 8 / 2001$ & 852.78 \\
\hline 12 & $2002-03$ & $28 / 6 / 2002$ & 1318.32 \\
\hline 13 & $2003-04$ & $25 / 8 / 2003$ & 560.02 \\
\hline 14 & $2004-05$ & $31 / 7 / 2004$ & 1535.81 \\
\hline 15 & $2005-06$ & $2 / 7 / 2005$ & 2603.15 \\
\hline Post implementation of Sardar Sarovar Project \\
\hline 16 & $2006-07$ & $30 / 7 / 2006$ & 1960.25 \\
\hline 17 & $2007-08$ & $2 / 7 / 2007$ & 1935.15 \\
\hline 18 & $2008-09$ & $12 / 8 / 2008$ & 1129.44 \\
\hline 19 & $2009-10$ & $8 / 7 / 2009$ & 1834.96 \\
\hline
\end{tabular}

\subsection{Summary of the Present Study}

Table-2: Water accumulated, Cu.m in various minors in Block-9B2 for year 1991-92 to 2005-06 without Considering of Crop water requirement

\begin{tabular}{|l|l|l|l|}
\hline $\begin{array}{l}\text { SR. } \\
\text { NO }\end{array}$ & YEAR & Base Day & $\begin{array}{l}\text { Water accumulated, } \\
\text { Cu.m }\end{array}$ \\
\hline 1 & $1991-92$ & $24 / 7 / 1991$ & 34128636 \\
\hline 2 & $1992-93$ & $13 / 8 / 1992$ & 26736849.4 \\
\hline 3 & $1993-94$ & $12 / 7 / 1993$ & 85692314.2 \\
\hline 4 & $1994-95$ & $7 / 9 / 1994$ & 208711534.4 \\
\hline 5 & $1995-96$ & $20 / 7 / 1995$ & 37058664 \\
\hline 6 & $1996-97$ & $28 / 7 / 1996$ & 69369444.6 \\
\hline 7 & $1997-98$ & $25 / 6 / 1997$ & 70200994.8 \\
\hline 8 & $1998-99$ & $15 / 9 / 1998$ & 99841735.8 \\
\hline 9 & $1999-2000$ & $18 / 6 / 1999$ & 21477242.8 \\
\hline 10 & $2000-01$ & $14 / 7 / 2000$ & 44925032.6 \\
\hline 11 & $2001-02$ & $16 / 8 / 2001$ & 58654208.4 \\
\hline
\end{tabular}




\begin{tabular}{|l|l|l|l|}
\hline 12 & $2002-03$ & $28 / 6 / 2002$ & 90674049.6 \\
\hline 13 & $2003-04$ & $25 / 8 / 2003$ & 38518175.6 \\
\hline 14 & $2004-05$ & $31 / 7 / 2004$ & 105633011.8 \\
\hline 15 & $2005-06$ & $2 / 7 / 2005$ & 179044657 \\
\hline
\end{tabular}

5. For Hetampura branch - 1.Drain of Hetampura minor the discharge carrying capacity is sufficient in case of year 1992-93 and 1999-2000.

6. For Hetampura Drain -3 of Hetampura minor the discharge carrying capacity is sufficient in case of year 1992-93 and 1999-2000.

Table-3: Water Accumulated in Block 9B2 In Phase-1 of

Sardar Sarovar Project with considering crop water requirement, (Cu.m./day) during Preimplemention of Sardar Sarovar Project

\begin{tabular}{|l|l|l|l|}
\hline $\begin{array}{l}\text { SR. } \\
\text { NO }\end{array}$ & YEAR & Base Day & $\begin{array}{l}\text { Water accumulated } \\
\text { considering CWR }\end{array}$ \\
\hline 1 & $1991-92$ & $24 / 7 / 1991$ & 34100926.59 \\
\hline 2 & $1992-93$ & $13 / 8 / 1992$ & 26680384.95 \\
\hline 3 & $1993-94$ & $12 / 7 / 1993$ & 85644911.94 \\
\hline 4 & $1994-95$ & $7 / 9 / 1994$ & 208629626.1 \\
\hline 5 & $1995-96$ & $20 / 7 / 1995$ & 37005685.01 \\
\hline 6 & $1996-97$ & $28 / 7 / 1996$ & 69345220.65 \\
\hline 7 & $1997-98$ & $25 / 6 / 1997$ & 70167360.11 \\
\hline 8 & $1998-99$ & $15 / 9 / 1998$ & 99797644.73 \\
\hline 9 & $1999-2000$ & $18 / 6 / 1999$ & 21442039.65 \\
\hline 10 & $2000-01$ & $14 / 7 / 2000$ & 44908650.94 \\
\hline 11 & $2001-02$ & $16 / 8 / 2001$ & 58623187.81 \\
\hline 12 & $2002-03$ & $28 / 6 / 2002$ & 90651916.93 \\
\hline 13 & $2003-04$ & $25 / 8 / 2003$ & 38490117.65 \\
\hline 14 & $2004-05$ & $31 / 7 / 2004$ & 105607567.9 \\
\hline 15 & $2005-06$ & $2 / 7 / 2005$ & 179029495.2 \\
\hline
\end{tabular}

Table-4: Water Accumulated in Block 9B2 in Phase-1 of Sardar SarovarProject with considering crop water requirement, (Cu.m./day) during Preimplemention of Sardar Sarovar Project

\begin{tabular}{|l|l|l|l|}
\hline $\begin{array}{l}\text { SR. } \\
\text { NO }\end{array}$ & YEAR & Base Day & $\begin{array}{l}\text { Water accumulated } \\
\text { considering CWR }\end{array}$ \\
\hline 1 & $2006-07$ & $30 / 7 / 2006$ & 134769032.2 \\
\hline 2 & $2007-08$ & $2 / 7 / 2007$ & 133093084.4 \\
\hline 3 & $2008-09$ & $12 / 8 / 2008$ & 77667659.4 \\
\hline 4 & $2009-10$ & $8 / 7 / 2009$ & 126177759.9 \\
\hline
\end{tabular}

1. During preimplementation considering without crop water requirement maximum water accumulated comes out to be 20871.15 Hac.m. and minimum water accumulated 3705.86 Ha.m. for year 1994-95 and 1995-96 respectively.

2. During preimplementation considering with crop water requirement maximum water accumulated comes out to be 20862.96 Hac.m. and minimum water accumulated $10560.75 \mathrm{Ha} . \mathrm{m}$. for year 1994-95 and 2004-05 respectively.

3. During Post implementation considering with crop water requirement maximum water accumulated comes out to be 13476.90 Hac.m. and minimum water accumulated 7766.76 Ha.m. for year 2006-07 and 2009-10 respectively.

4. For Hasipura palaswada drain of Hetampura minor the discharge carrying capacity is sufficient in case of year 1992-93 and year 1999-2000.

\section{CONCLUSIONS}

1. The runoff evaluation can also be carried out for all other minors in block- $9 \mathrm{~B}_{2}$

2. Similar type of study can also be carried out for all other remaining blocks of sardar Sarovar Project.

\section{REFERENCES}

[1]. Frank van steen Bergen, "Irrigation modernization: constrains \& solutions syria”, 2006.

[2]. F.H.W. Green, "Quantification of areas of agricultural and forestry drainage as they affect extrapolation of the results of representative \& experimental basins", Department of agriculture science, University of Oxford, U.K, 1980.

[3]. Dr. K.R. Arora, "Irrigation, water power and water resources engineering", Standard Publishers and Distributors, Delhi, 2008.

[4]. Abdul-Dayam, S., "Drainage experience in arid and semi-arid regions on agricultural drainage development in humid tropic regions". In Proceedings of the $8^{\text {th }}$ ICID International Drainage Workshop, Vol. 1, New Delhi, 2000 [5]. Ahmad, M. "Irrigation and drainage policies in the Near East", In Proceedings of the $8^{\text {th }}$ ICID international drainage workshop, Vol. 3, New Delhi, 2000.

[6]. Datta, D., Gawr K.K. \& Singh, J. "The importance of social variables in drainage projects",In Proceedings of the $8^{\text {th }}$ ICID International Drainage Workshop, Vol. 1, New Delhi, 2000.

[7]. Girishbhai K. Vaghela,"Performance study of drainage \& salinity control in the pilot project at Dabhou of Mahi Right Bank canal command", 1989.

[8]. Government of Gujarat Water resources department, Guide line for planning and design of micro canal network system, 1989.

[9]. Govt. of Gujarat irrigation department Narmada planning Group, Report Journals Volume-1 on Drainage \& Conjunctive use Strategy sardar sarovar (narmada) project development plan.

[10]. Guidelines for predicting crop water requirement Food \& Agriculture organization of united Nations, FAO-24, Rome-1977.

[11]. FAO 61, Irrigation and drainage paper on agricultural drainage water management in arid and semi-arid areas, ROME, 2002.

[12]. ICID Report Volume-V, $3{ }^{\text {rd }}$ Congress on Irrigation \& Drainage, Delhi, 1957.

[13]. FAO 62 guidelines and Computer programme for the planning and design of land drainage system, 2007.

[14]. FAO CROPWAT-8, FAO methodologies on crop water estimating reference crop Evapotraspiration, 2001. 
[15]. M.M. Pandey, Indian agriculture -An introduction, $4^{\text {th }}$ session of the technical committee of APCAEM, Thiland, 2009.

[16]. R.N. Consultancy service, Drainage network Reports, statements, maps, volume: I-A for Block $9 \mathrm{~B}_{2}$ in Phase-I of Sardar Sarovar (Narmada) Project.), Provided by Office of Dy. Ex. Engineer, Narmada canal division No. 10/4 Sardar Sarovar Narmada Nigam Ltd. Channi, Vadodara, 1990.

[17]. S.K. Gupta. R.K. Singh and R.S. Pandey, Surface drainage requirement of crops: application of a piecewise linear model for evaluating submergence tolerance, Central Soil salinity, research Institute karnal, 1992.

[18]. Vaghera, S.G.K., Shah, C.R., Shete, S.D.T., Parthasathy, G.S. \& Modi, P.M. 1995, Performance study of drainage and salinity control in the pilot project at Dabhou, Mahi Right Bank Canal Command, In Proceedings of the special technical session, Vol. 2, Rome, ICID.

[19]. Food and agriculture organization, International programme for technology and research in irrigation and drainage, ( IPTRID) (ROOM), 2006.

[20]. Indian Association of Hydrologists Report Journals on proceedings of the Seminar on estimation of runoff for surface \& Subsurface Drainage, New-Delhi, 1985.

\section{BIOGRAPHIES}

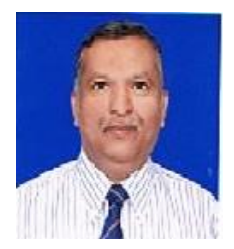

Prof.S.G.Khokhar completed B.E in Civil Engineering in 1996 from University of Pune (M.S) and M.E. Civil (Irrigation water management) in 2010 from The MS University of Baroda (Gujarat). Author has 9 years Teaching Experience \& 11 years Construction Industry experience. $\mathrm{He}$ is working as Assistant Professor \& Head in Civil Engineering Department at Parul Institute of Engineering \& Technology, Waghodia .Vadodara (Gujarat).

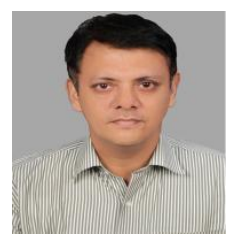

Siddharth N.Gupte completed B.E in Civil Engineering in 1994 from BVM Engineering College, Sardar Patel University, Vallabh Vidyanagar, (Gujarat)) and pursuing M.E. Civil (Transportation Engineering) from Parul Institute Of Engineering and Technology, Waghodia (Gujarat). Author has 2 years Teaching Experience \& 11 years Construction Industry experience.

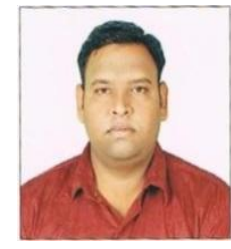

Vikram J. Patel completed B.E. in Civil Engineering in 2011 and M.E. Civil (Transportation Engineering) in 2013 from Parul Institute of Engineering \& Technology, Waghodia, Vadodara. Presented 02 research papers in National conference and published 02 research papers in International journal. Along with the presentations author had attended 04 workshops sponsored by ISTE. Author has 2.6 years teaching Experience \& from last 07 months he is working as Assistant Professor in Civil Engineering Department at R. C. Patel Institute of Technology, Shirpur, and Dist. Dhule (MS). 